\title{
Introduction to Section 1
}

\section{Religious experience: a difficult thing to engage with}

In approaching the topic of religious experiences, a writer always runs the risk of making arbitrary assumptions, as a brief survey of the academic debate on the topic reveals. For more than a century, scholars working in philosophy, psychology of religion, anthropology of religion, religious studies, and many other disciplines besides, have been engaged in a debate about the correct way to approach experiences in general and religious experiences in particular. Support has oscillated between subjectivist and constructivist poles, which is to say the ideas that religious experience is either something highly individual, something intrinsic and authentic, or something that is the result of culture and society. ${ }^{1}$ In recent years, a broader critique of the notion of religious experience itself has also developed. R. Sharf (2000), for instance, has argued that the idea of an experience deemed religious or divine is itself intrinsically tied to Western conceptions of religion and religiosity, which prioritize, or even overvalue, experiences as pivotal points of human practice.

Sharf's criticism is primarily directed towards philosophical approaches to religious experience. Scholars contributing to this debate have tended to maintain a normative, indeed essentializing, approach that focuses on religious experience, rather than religious experiences. With the exception of F. Schleiermacher, one of the first and most influential thinkers to work on this topic (Martin 2016, 526-527), the most prominent protagonists in this respect tended to be early pragmatists and phenomenologists. Just as pragmatism, represented by W. James' highly influential The Varieties of Religious Experience, the phenomenology of religion (W. Dilthey. J. Wach and M. Eliade) $)^{2}$ "enjoins the 'imaginative participation in the world of the actor' in order to arrive at 'value free' and 'evocative' descriptions" (Sharf 2000, 268 quoting Smart 1973, 20-21). Due to the new technological devices that neuroscience appears to offer for the study of religions, these essentialist approaches have undergone a renaissance in recent decades. Despite the questionable scientific bases of their 19th century's predecessors experiments in magnetism

1 For a brief, even though outdated overview, see Proudfoot 1985; Taves 2009, 3-14.

2 A comprehensive overview offered by Murphy 2010.

Ә Open Access. ( 2020 Maik Patzelt, published by De Gruyter. (c) BY-NC-ND This work is licensed under a Creative Commons Attribution-NonCommercial-NoDerivatives 4.0 International License.

https://doi.org/10.1515/9783110557596-002 
and other fields of popular psychology (cf. Taves 1999), ${ }^{3}$ cognitive scientists, neuroscientists, and, particularly, neuro-psychologists of religion (who tend to term themselves neuro-theologists), ${ }^{4}$ have not been deterred from seeking to identify religious experiences as anthropological constants, universal truths that are encoded as inherent elements in the human brain.

These essentializing approaches - as varied as they are - mainly build on a notion of religious practice that ignores its embodied dimensions. However, recent discussions in the cognitive science of religion, ${ }^{5}$ as well as research on the senses in religion, focusing particularly on aesthetics and mediality, ${ }^{6}$ have foregrounded an embodied approach to religious practice and experience. The emphasis here is on a non-Cartesian dialectical interaction between the body, the mind (or rather the brain), and the cultural and social environments in which body and brain are embedded (Kundtová Klocová and Geertz 2019, 76-80; Geertz 2010, 306-308). These studies do not consider religious experience as essentialized or as an anthropological constant or as something solely derived from a neurological core. Rather, they ask "How are the senses stimulated, governed and disciplined in the context of religious practice?" and "How are religious experiences, emotions and attitudes created, memorized and normalized?" (Grieser and Johnston 2017, 2).

From this perspective, religious experiences are not to be reduced to various aesthetic qualities - such as (flashing) lights, fragrances, or rhythmic sounds and performances (Geertz 2010, 306-308). ${ }^{7}$ An embodiment approach focuses instead on the "interplay between sensory, cognitive and socio-cultural aspects of world-construction” (Grieser and Johnston 2017, 2). Religious experiences are, thus, above all culturally learned and socially evoked. These experiences only

3 Their early 20th century predecessors are K. Girgensohn (1921) or T.K. Oesterreich (1921). Their and many other approaches are reminiscent of Schleiermacher or particularly R. Otto ([1917] 1991), who sought to cull a particular experience as an anthropological constant, such as Ottos's Kreaturgefühl.

4 Most prominent figures are A. Newberg (2010, cf. d'Aquili and Newberg 1999) or Forman (1999). For positions against these views see Geertz 2010, 305; Schjoedt 2009; Azari et al. 2005; McNamara 2009.

5 Czachesz 2016, 8-23; Taves 2015; Schjoedt 2009; McNamara 2009; Azari et al. 2005; Whitehouse 2004; McCauley and Lawson 2002. For a general overview see Hick 2010.

6 Meyer 2010, 2008; Classen 2014; Classen and Howes 2014; Münster 2001; Kapferer and Hobart 2005; Cancik and Mohr 1988. A broad approach to mediality and religion is provided by Malik, Rüpke and Wobbe 2007.

7 On music, sounds and movements: Brown and Volgsten 2006; McCauley and Lawson 2002; Laderman 1991; Roseman 1986; Kapferer 1983, 178-206; on postures: Niedenthal et al. 2005; Barsalou et al. 2003; on pain: Ustinova 2019; Schjoedt et al. 2013. 
have significance within a particular culture, within a particular social environment (status, milieu, etc.), and within the specific moment and social gathering in which they are evoked, negotiated, and communicated. ${ }^{8}$ In the words of Tanya Luhrmann, every culture and every individual within "cultivates" its own ways of "sensing" the religious. ${ }^{9}$ More precisely, it is the cultural- and milieu-specific recollection of these experiences, such as symbolic constructions (e.g. narratives) and representations (e.g. statues), that determines our ways of detecting a religious experience, most of all conceptualized as an experience of superhuman agency. ${ }^{10}$ These forms of knowledge and commemoration are (re)produced, nuanced, and actualized through communication.

An embodied approach of this sort leaves scholars of religion - and particularly historians of religion - with the problem of the communicability of experiences (see Jung 2006, 1999; Knoblauch 1998) and the interpretive dominance of religious specialists (Bendlin 2015, 538). There are many factors that complicate a coherent analysis of communicability. These range from the almost endless variety of individual (religious) knowledge, which may or may not be ascribed to an equally endless variety of neuro-physical 'manipulations' and arousals, or to the complexity of intersubjective negotiation processes in social gatherings (cf. Csordas 2008). However, the factor with which historians of religions are primarily concerned is the limited and fragmented historical evidence that complicates these efforts. This problem touches the very heart of the study of past cultures, that is, the expressive limits of language (cf. N. Belayche in this volume), the semiotics of architectural and poetic language, and the 'meaning' of ritual practice. The study of the experiences of the past thus requires a great deal of effort to, first and foremost, disclose and reconstruct the cultural, social, situational, and particularly the ritual context and the related discourses. As R. Gordon points out in this volume, religious experience "is at any rate communicable only via the relevant constructs available in a given culture or sub-culture". The historian of religion, and particularly the historian of ancient religions, faces a difficult challenge in not reducing experiences to purely subjectivist frameworks while, at the same time, avoiding the development of normative generalizations about coherent group experiences. This latter case would amount to little more than the transfer of a civic religion model to a smaller scale of analysis.

8 Czachesz 2015, 7; Geertz 2010, 315-318; Taves 2009, 16-55; Barsalou et al. 2005. From a performative point of view see Schieffelin 1996.

9 Luhrmann 2013; Luhrmann and Morgain 2012.

10 The recent debate in the cognitive science of religion models this process as "predictive processing", "predictive coding" or the "predictive mind" in general (Andersen 2019; Andersen et al. 2019; Andersen and Schjoedt 2017). 
The present volume seeks to take up this challenge. The embodiment approach to experience avoids reducing experiences to a culturally normative set of meanings, as is pointed out by Sharf, and it is precisely for this reason that the "lived ancient religion"-approach pursues an embodiment approach to religious practice and experience. The "lived ancient religion"-approach furthermore seeks to enhance the embodiment approach by introducing the concept of agency (Rüpke 2015). A "lived ancient religion"-approach to experience, thus, acknowledges the social world in which the agent is embedded - the individual's cultural and social belonging - just as it acknowledges the individual's capacity to appropriate different strategies for eliciting sensory, emotional, and cognitive responses, as well as for expressing and communicating personal experiences (de Certeau 1984). ${ }^{11}$

This section of the volume, therefore, aims at bringing to the fore the contexts of experiences underlying religious action and at identifying the discourses that diffuse, debate, and negotiate these experiences from the Early Empire to the beginnings of late antiquity. The production of sensory stimuli in religious rituals is just as interesting as are the spatial, temporal, and discursive contexts that favor interpretations of a given phenomenon as "religious", "mystical”, or in some sense "divine". Given the various strategies for eliciting, identifying and communicating the formation of religious experiences, the embodiment approach of this section provides a first tentative attempt to look for the variety of experiences that are encoded within and between the variety of cultures across time and space (cf. Martin 2012, 188-196).

The chapters that follow are driven by questions such as: How can we detect religious experience and techniques towards them in our sources and how does that affect our overall view of religiosity, religious belief, and religious practice in antiquity? In what contexts do we find reference to specifically religious experience? How did people try to communicate, memorize and contour their experiences through the channels available to them, such as the re-use of mythical narratives or the setting up of material objects? How did architectural spaces and objects allow for or stimulate religious experiences?

\section{Research on ancient religions}

In recent years, there has been an increasing, yet disparate interest in the experiential quality of ancient religions. Most of these approaches are strongly

11 Cognitive scholars may speak about an enactive embodiment (Kundtová Klocová and Geertz 2019, 78-80). 
informed by either the cognitive science of religion or by the anthropology of the senses and emotions. Cognitive studies mainly engage with particular cult systems, examining their specific sensescapes and modes of memory. Most of the studies collected here concentrate on Greek cults (Ustinova 2019, 2009; Panagiotidou 2017, 2014; Chalupa 2014) and early Christianity (Czachesz 2015, 2016; Harkins and Popović 2015). Similarly, recent scholarship on the anthropology of the senses and sensorium in both ancient religion ${ }^{12}$ and early Christianities (Feldt 2017; Pentcheva 2014), particularly Christian asceticism (Alciati 2018), has initiated a debate about the social and cultural significance of sensory stimulations, emotions, arousals, and affections. As for Rome, addressing the issue of emotions has been a rather difficult challenge due to the history of research into Roman religion (Bendlin 2006, 2000). Only recently have first attempts been made to approach more closely the experiential aspects of Roman religion in the late Republican and early Imperial eras (Rüpke 2016, 218-269; Patzelt 2018, 18-45; Cusumano et al. 2013; vs. Scheid 2015, 113-118). These attempts seek to overcome the still prevailing dichotomy between institutionalized religion and individual religiosity in favor of an embodiment approach.

Due to differing cultures of academic disciplines and due to a variety of problems with the source material, all these approaches to Greek, Roman, and Christian religions place differing degrees of emphasis on the importance of agency, collective memory, and group religion in their roles as requisites for experiences or ways in which experiences are expressed. There is barely any interchange between these disciplines in this regard. Since such communication is essential if we are to reconsider the perspectives and methods of each discipline, this section draws together a broad range of methodological approaches to a variety of materials undertaken by scholars of Roman religions, Greek religions, and early Christianities.

\section{Individual contributions in the section}

The value of this book section is to bring together different perspectives and approaches from disciplines that have so far had little overlap. Corresponding to the conference's original credo of "leaving the disciplinary comfort zone", this

12 Alvar et al. 2019; Harvey 2006; Chaniotis 2016, 2013. Recent but general approaches to synesthesia and the senses in antiquity in Toner 2016; Grand-Clément 2016; Bradley 2015; Butler and Purves 2013. 
section seeks to encourage scholars of various disciplines to come into contact, to exchange ideas, and, finally, to cross boundaries and to rethink their views and perspectives about, and problems with, both the material and their methods for approaching it. In so doing, this section suggests various methodological perspectives that bring together aspects of agency, group memory, communication, and experience. This range of perspectives is applied to a wide scope of disciplines such as theology, philology, and history - that focus on the study of ancient religion. The variety of religious practices (daily rituals, pilgrimage, cursing, praying, singing, drinking, mutilations), spaces (Rome, Corinth, Egypt, Asia Minor, Thracia), and times (1st to late 3rd century CE) covered here is, therefore, as essential for this section as is the variety of experiences (ecstasies, possessions, ordinary experiences) highlighted in the inevitably wide range of employed sources (inscriptions, letters, apocalyptic texts, hymns).

Given the problems of communicating experiences found within the media accessible to us, Richard Gordon argues that scholars should speak about "requisite" experiences rather than "special" or "subjective" experiences. In his case study, Gordon tentatively reconstructs a perceptual framework that may or may not indicate the formation of religious experiences in an ideal highly educated group of social elites. Based on the reader-response theory and a rigorous analysis of hymnic techniques, such as the use of epithets, mythic allusions, and references, Gordon examines how and to what extent the composition of works such as Orphic hymns or Aelius Aristides' Hymn to Serapis conveyed intuitions and apprehensions of divinity to their audiences and/or performers.

Angela Kim Harkins addresses the problem of group memory and experience from another point of view. Drawing on cognitive science, she introduces the concepts of enactive reading and enactive perception and uses these to analyze the visionary experiences found within the Shepherd of Hermas, particularly the encounter with Rhoda and the Vision of the Tower. By analyzing the emotional contours of mythic references and narratives (e.g. the story of Reuben and Bilhah), these two modes of perception and cognition allow insights into how the ancients experienced reading about the visionary events reported in the Shepherd. These modes also offer insights into the writer's strategy of tying in, and thereby transforming, the ascription processes of his readers. Harkins argues that the processes of enactive reading and enactive perception "act upon" the selves of the readers and, consequently, participate in their decision-making processes, that is, in the construction of ethical constraints on behavior.

Maria Dell'Isola focuses on the discourse about, indeed against, religious experiences in relation to their geneses. Drawing primarily on the Church Fathers Epiphanius, Philo, Eusebius, and Origen, Dell'Isola's study reconstructs a "phenomenology" of ecstasy. As she points out, strategies directed towards achieving 
states of ecstasy and experiences of possession did not necessarily differ in early Christianity. However, the judgments of the individual writers did. Dell'Isola's philological study reveals the vocabulary of anti-Montanist polemics as a strategy of stigmatization within the 'heresiological' debates of early Christianity. Her approach thus emphasizes strategies of evoking, as well as of constructing, religious experiences for the sake of group formation.

Nicole Belayche takes the risky approach of identifying religious experiences on the basis of fragmentary epigraphic material, leading to ground-breaking results. By concentrating her philological approach on the invocative options kýrios/a and despótes, Belayche does not merely elucidate two possible options for expressing a worshipper's personal submission. Her comparative approach, examining material from Thrace to Egypt to the Levant, rather illustrates a wide scope of religious experiences that are expressed and communicated using these epithets. According to Belayche, the invocation despótes in particular seeks to express a very intense and very personal experience, as there is mention in this context of such things as oracular advice and dreams.

Maik Patzelt addresses ways of eliciting religious experiences from another perspective. By applying a recent pragmatist discourse concerning "ordinary experiences" to the ancient material, he argues that there is no need to restrict experiences deemed "special" or "divine" to those that are arousing or "special" in some other way (a general criticism of such assumptions can be found in Sharf 2000, 285). The salutationes in front of Roman temples serve as a case study that illuminates the variety of individual strategies aiming to establish a personal relationship with the addressed deity. The variety of religious experiences thus stems from the variety of personal, highly nuanced social relationships with a deity.

Ian Rutherford provides an important contribution to the understanding of the variety of experiences at ancient pilgrimage sites. Focusing on the relation between paideia and ritual practice, Rutherford sets out three case studies covering Jewish pilgrimage, pilgrimage to the oracle of Apollo at Claros, and the healing-pilgrimages of Aelius Aristides to Pergamum. These case studies highlight different forms of subjective experience and, by doing so, allow deep insights into the importance of cult(ural) and even milieu-specific religious knowledge. Rutherford's approach thereby highlights the interrelation between an evocative religious space (rites of passage, communitas) and the various things that the pilgrims' bodies undergo, such as the strains (and pains) of travel and religious practices.

Irene Salvo has contributed a most compelling approach to the reconstruction of aesthetic qualities, which she considers as strategies for neuro-physical manipulations. She sketches the cognitive and embodied aspects of the cursing ritual as a multi-sensory experience. Her analysis of the archaeological and 
ritual settings in the sanctuary of Demeter and Kore in Corinth (1st to 2nd century $\mathrm{CE}$ ), the sanctuary of Isis and Magna Mater in Mainz (1st to 2nd CE), and, finally, in the fountain of Anna Perenna in Rome (2nd to 5th $\mathrm{CE}$ ) provides a reconstruction of the ritual sensescape. In her approach, the variety of sensory stimuli (lights, fragrances and so on) was able to modify - in the ideal case heighten - the emotions of participants. Salvo thereby refers to the thin line between the goal of shifting the emotions by the careful use of lead, on the one hand, and lead poisoning, on the other.

Paul's so-called "Second Letter to the Corinthians" is an outstanding example of the genesis and diffusion of religious experiences in the New Testament. Analyzing the alleged "ego-documents" of Paul in these Corinthian letters, Oda Wischmeyer illustrates Paul's shift from heavenly experiences to the experiences of the body, thereby turning to his body as place and bearer of revelation. She argues that rather than heavenly visions, experiences emanating from permanent suffering through hardship and disease constructed the religious authority of Paul. Paul employs his disease as an actual revelation of the cháris and the dýnamis of the kýrios. Just as the Shepherd of Hermas, Paul uses his personal experiences as normative ascriptions of religious experiences with which he sought to support and lead the Corinthian Christian groups.

Taken together, these chapters demonstrate the ground-breaking value of the "lived religion" perspective. It is the variety of (embodied) experience the variety of contexts, of stimuli, and the variety of cultural and social formations - that gives this approach its strength. Instead of categorizing these phenomena according to their various aspects and types of experience, this section considers the phenomena for what they are: a broad range of culturally specific experiences that only have significance within the moments and within the social contexts in which they are evoked.

\section{Bibliography}

Alciati, Roberto 2018. 'The Ascetic Knowledge: The Importance of Sense-Perception in Ancient Christian Asceticism,' Religion of the Roman Empire 4. 45-62.

Alvar, Anton et al. (eds) 2019. Sensorium: Sensory Perceptions in Roman Polytheism. Leiden. Andersen, Marc 2019. 'Predictive Coding in Agency Detection', Religion, Brain \& Behavior 9. 65-84.

Andersen, Marc; Pfeiffer, Thies; Müller, Sebastian; Schjoedt, Uffe 2019. 'Agency Detection in Predictive Minds: A Virtual Reality Study', Religion, Brain, and Behavior 9. 52-64. Andersen, Marc; Schjoedt, Uffe 2017. 'How does Religious Experience Work in Predictive Minds?' Religion, Brain, and Behavior 7. 320-323. 
Azari, Nina P. et al. 2005. 'Religious Experience and Emotion. Evidence for Distinctive Cognitive Neural Patterns', The International Journal for the Psychology of Religion 75. 263-281.

Barsalou, Lawrence W. et al 2003. 'Social Embodiment,' The Psychology of Learning and Motivation. Advances in Research and Theory 43. 43-92.

Barsalou, Lawrence W. et al. 2005. 'Embodiment in Religious Knowledge', Journal of Cognition and Culture 5. 14-57.

Bendlin, Andreas 2000. 'Looking Beyond the Civic Compromise: Religious Pluralism in Late Republican Rome.' In Religion in Archaic and Republican Rome and Italy: Evidence and Experience, ed. Edward Bispham, Christopher Smith. Edinburgh. 115-135.

Bendlin, Andreas 2006. ,Eine wenig Sinn für Religiosität verratende Betrachtungsweise: Emotion und Orient in der römischen Religionsgeschichtsschreibung der Moderne', Archiv für Religionsgeschichte 8. 227-256.

Bendlin, Andreas 2015. 'Review: "Nicola Cusumano et al. (eds.). Memory and Experience in the Greco-Roman World. Stuttgart 2013”', Bonner Jahrbücher 215. 537-541.

Boyer, Pascal 2001. Religion Explained: The Evolutionary Origins of Religious Thought. London.

Bradley, Mark (ed.). 2015. Smell and the Ancient Senses. London.

Brown, Steven; Volgsten, Ulrike (eds) 2006. Music and Manipulation: On the Social Uses and Social Control of Music. New York.

Butler, Shane; Purves, Alex (eds) 2013. Synesthesia and the Ancient Senses. London.

Cancik, Hubert; Mohr, Hubert 1988. 'Religionsästhetik.' In Handbuch religionswissenschaftlicher Grundbegriffe. Vol. 1, Systematischer Teil. Alphabetischer Teil: Aberglaube - Antisemitismus, ed. Hubert Cancik, Burkhard Gladigow, Matthias Laubscher. Stuttgart. 121-156.

Chalupa, Aleš 2014. 'Pythiai and Inspired Divination in the Delphic Oracle: Can Cognitive Sciences Provide Us with an Access to "Dead Minds"?', Journal of Cognitive Historiography 1. 24-51.

Chaniotis, Angelos 2013. 'Staging and Feeling the Presence of God: Emotion and Theatricality in Religious Celebrations in the Roman East.' In Panthée: Religious Transformations in the Graeco-Roman Empire, ed. Laurent Bricault, Corinne Bonnet. Leiden. 169-189.

Chaniotis, Angelos 2016. 'Displaying the Emotional Community: The Epigraphic Evidence.' In Emotion and Persuasion in Classical Antiquity, ed. Ed Sanders, Matthew Johncock. Stuttgart. 93-111.

Classen, Constance (ed.) 2014. A Cultural History of the Senses. 6 volumes. London.

Classen, Constance; Howes, David 2014. Ways of Sensing: Understanding the Senses in Society. London.

Csordas, Thomas J. 2008. 'Intersubjectivity and Intercorporeality', Subjectivity 22. 110-121.

Cusumano, Nicola; Gasparini, Valentino; Mastrocinque, Attilio; Rüpke, Jörg (eds) 2013. Memory and Experience in the Greco-Roman World. PAwB 45. Stuttgart.

Czachesz, István 2015. 'Religious Experience in Mediterranean Antiquity: Introduction to the Special Issue,' Journal of Cognitive Historiography 2. 5-13.

Czachesz, István 2016. Cognitive Science and the New Testament: A New Approach to Early Christian Research. Oxford.

D’Aquili, Eugene; Newberg, Andrew B. 1999. The Mystical Mind: Probing the Biology of

Religious Experience. Minneapolis.

de Certeau, Michel 1984. The Practice of Everyday Life. Berkeley. 
Feldt, Laura 2017. 'The Literary Aesthetics of Religious Narratives: Probing Literary-Aesthetic

Form, Emotion, and Sensory Effects in Exodus 7-11.' In Aesthetics of Religion: $A$

Connective Concept, ed. Alexandra K. Grieser, Jay Johnston. Berlin. 121-143.

Forman, Robert K.C. 1999. Mysticism, Mind, Consciousness. Albany.

Geertz, Armin W. 2010. 'Brain, Body and Culture: A Biocultural Theory of Religion', Method and Theory in the Study of Religion 22. 304-321.

Girgensohn, Karl 1921. Der seelische Aufbau des religiösen Erlebens: Eine religionspsychologische Untersuchung auf experimenteller Grundlage. Leipzig.

Goldie, Peter 2000. The Emotions: A Philosophical Exploration. Oxford.

Grand-Clément, Adeline 2016. 'Colori e sensi: percepire la presenza divina.' In Gli dèi di Omero: Politeismo e poesia in Grecia antica, ed. Corinne Bonnet, Gabriella Pironti. Rome. 59-84.

Grieser, Alexandra; Johnston, Jay 2017. 'What is an Aesthetics of Religion? From the Senses to Meaning - and Back Again.' In Aesthetics of Religion: A Connective Concept, ed. Alexandra K. Grieser, Jay Johnston. Berlin. 1-49.

Harkins, Angela K. 2015. 'The Emotional Re-Experiencing of the Hortatory Narratives Found in the Admonition of the Damascus Document', Dead Sea Discoveries 22. 285-307.

Harkins, Angela K.; Popović, Mladen (eds) 2015. 'Religious Experience and the Dead Sea Scrolls', Dead Sea Discoveries 22. Special Issue. 247-357.

Harvey, Susan A. 2006. Scenting Salvation: Ancient Christianity and the Olfactory Imagination. Berkeley.

Hick, John 2010. The New Frontier of Religion and Science: Religious Experience, Neuroscience and the Transcendent. Basingstoke.

Jung, Matthias 1999. Erfahrung und Religion: Grundzüge einer hermeneutisch-pragmatischen Religionsphilosophie. Freiburg i. Br.

Jung, Matthias 2006. 'Making Life Explicit: The Symbolic Pregnance of Religious Experience', Svensk Teologisk Kvartalskrift 82. 16-23.

Jung, Matthias 2014. Gewöhnliche Erfahrung. Tübingen.

Kapferer, Bruce 1983. A Celebration of Demons: Exorcism and the Aesthetics of Healing in Sri Lanka. Bloomington.

Kapferer, Bruce; Hobart, Angela (eds) 2005. Aesthetics in Performance: Formations of Symbolic Construction and Experience. New York.

Knoblauch, Hubert 1998. 'Transzendenzerfahrung und symbolische Kommunikation: Die phänomenologisch orientierte Soziologie und die kommunikative Konstruktion von Religion'. In Religion als Kommunikation, ed. Hubert Knoblauch, Hartmann Tyrell, Volkhard Krech. Würzburg. 147-186.

Kundtová Klocová, Eva; Geertz, Armin W. 2019. 'Ritual and Embodied Cognition.' In The Oxford Handbook of Early Christian Ritual, ed. Risto Uro et al. Oxford. 74-94.

Laderman, Carol 1991. Taming the Winds of Desire: Psychology, Medicine, and Aesthetics in Malay Chamanistic Performances. Berkeley.

Lewis, Ioan M. [1971] 2003. Ecstatic Religion: A Study of Shamanism and Spirit Possession. London.

Luhrmann, Tanya 2013. “"Lord, Teach Us to Pray”: Prayer Practice Affects Cognitive Processing', Journal of Cognition and Culture 13. 159-177.

Luhrmann, Tanya; Morgain, Rachel 2012. 'Prayer as Inner Sense Cultivation: An Attentional Learning Theory of Spiritual Experience', ETHOS 40. 359-389. 
Malik, Jamal; Rüpke, Jörg; Wobbe, Theresa (eds) 2007. Religion und Medien: Vom Kultbild zum Internetritual. Vorlesungen des Interdisziplinären Forums Religion der Universität Erfurt. Münster.

Martin, Craig 2012. 'William James in Late Capitalism: Our Religion of the Status Quo.' In Religious Experience: A Reader, ed. Craig Martin, Russell T. McCutcheon. Sheffield. 177-196.

Martin, Craig 2016. 'Experience.' In The Oxford Handbook of the Study of Religion, ed. Michael Stausberg, Steven Engler. Oxford. 525-540.

McCauley, Robert N.; Lawson, E. Thomas 2002. Bringing Ritual to Mind: Psychological Foundations of Cultural Forms. Cambridge.

McNamara, Patrick 2009. The Neuroscience of Religious Experience. Cambridge.

Meyer, Birgit 2008. 'Media and the Senses in the Making of Religious Experience: An Introduction,' Material Religion 4. 124-135.

Meyer, Birgit (ed.) 2010. Aesthetic Formations: Media, Religion, and the Senses. Basingstoke. Münster, Daniel 2001. Religionsästhetik und Anthropologie der Sinne: Vorarbeiten zu einer Religionsethnologie der Produktion und Rezeption ritueller Medien. München.

Murphy, Timothy 2010. The Politics of Spirit: Phenomenology, Genealogy, Religion. Albany. Newberg, Andrew 2010. Principles of Neurotheology. Farnham.

Niedenthal, Paula M. et al. 2005. 'Embodiment in Attitudes, Social Perception, and Emotion', Personality and Social Psychology Review 9. 184-211.

Oesterreich, Traugott K. 1921. Die Besessenheit. Langensalza.

Otto, Rudolf [1917] 1991. Das Heilige: Über das Irrationale in der Idee des Göttlichen und sein Verhältnis zum Rationalen. München.

Panagiotidou, Olympia 2014. 'The Asklepios Cult: Where Brains, Minds, and Bodies Interact With the World, Creating New Realities', Journal of Cognitive Historiography 1.14-23.

Panagiotidou, Olympia 2017. The Roman Mithras Cult: A Cognitive Approach. London.

Patzelt, Maik 2018. Über das Beten der Römer: Gebete im spätrepublikanischen und frühkaiserzeitlichen Rom als Ausdruck gelebter Religion. Berlin.

Pentcheva, Bissera 2014. 'The Power of Glittering Materiality: Mirror Reflections Between Poetry and Architecture in Greek and Arabic Medieval Culture', Ancient Near Eastern Studies. Supplementa 47. 223-268.

Plamper, Jan 2015. The History of Emotions: An Introduction. Oxford.

Proudfoot, Wayne 1985. Religious Experience. London

Revonsuo, Antti et al. 2009. 'What is an Altered State of Consciousness?' Philosophical Psychology 22. 187-204.

Roseman, Marina L. 1986. Sound in Ceremony: Power and Performance in Temiar Curing Rituals. Diss. Cornell University.

Rouget, Gilbert 1985. Music and Trance: A Theory of the Relations Between Music and Possession. Chicago.

Rüpke, Jörg 2015. 'Religious Agency, Identity, and Communication: Reflections on History and Theory of Religion', Religion 45. 344-366.

Rüpke, Jörg 2016. Pantheon: Geschichte der antiken Religionen. München.

Scheid, John 2015. The Gods, the State, and the Individual: Reflections on Civic Religion in Rome. Philadelphia.

Schieffelin, Edward L. 1996. 'On Failure and Performance: Throwing the Medium Out of the Séance.' In The Performance of Healing, ed. Carol Laderman, Marina Roseman. London. 59-90. 
Schjoedt, Uffe 2009. 'The Religious Brain: A General Introduction to the Experimental Neuroscience of Religion', Method and Theory in the Study of Religion 21. 310-339.

Schjoedt, Uffe et al. 2013. 'Images from a Jointly-Arousing Collective Ritual Reveal Affective Polarization', Frontiers in Psychology 4. 1-11.

Sharf, Robert H. 2000. 'The Rhetoric of Experience and the Study of Religion', Journal of Consciousness Studies 7. 267-287.

Smart, Ninian 1973. The Science of Religion and the Sociology of Knowledge: Some Methodological Questions. Princeton.

Taves, Ann 1999. Fits, Trances, \& Visions: Experiencing Religion and Explaining Experience from Wesley to James. Princeton.

Taves, Ann 2009. Religious Experience Reconsidered: A Building Block Approach to the Study of Religion and Other Special Things. Princeton.

Taves, Ann 2015. 'Reverse Engineering Complex Cultural Concepts: Identifying Building Blocks of "Religion”, Journal of Cognition and Culture 15. 191-216.

Toner, Jerry (ed.) 2016. A Cultural History of the Senses in Antiquity. London

Ustinova, Yulia 2009. Caves and the Ancient Greek Mind: Descending Underground in the Search for Ultimate Truth. Oxford.

Ustinova, Yulia 2018. Divine Mania: Alteration of Consciousness in Ancient Greece. London.

Ustinova, Yulia 2019 (forthcoming). 'Hirpi Sorani and Modern Fire-Walkers: Rejoicing through Pain in Extreme Rituals.' In Sensorium: Sensory Perceptions in Roman Polytheism, ed. Anton Alvar, Greg Woolf. Leiden.

Whitehouse, Harvey 2004. Modes of Religiosity: A Cognitive Theory of Religious Transmission. Oxford. 